\title{
INTRODUKSI ALAT PENGERING TIPE RAK BERPUTAR SEBAGAI UPAYA MEMPERCEPAT PROSES PENGERINGAN HASIL PETANIAN
}

\author{
Sukmawaty ${ }^{1^{*}}$, Asih Priyati ${ }^{2}$, Guyup Mahardhian Dwi Putra ${ }^{3}$, \\ Diah Ajeng Setiawati ${ }^{4}$, Sirajuddin Haji Abdullah ${ }^{5}$ \\ ${ }^{1,2,3,4,5}$ Program Studi Teknik Pertanian, Universitas Mataram, Indonesia \\ sukmawaty14@yahoo.com ${ }^{1}$, r_yuhaeri@yahoo.com ${ }^{2}$, guyupmdp@unram.ac.id ${ }^{3}$, \\ diahajengs@unram.ac.id ${ }^{4}$, sirajuddinhajiabdullah@gmail.com ${ }^{5}$
}

\begin{abstract}
ABSTRAK
Abstrak: Pengeringan didefinisikan sebagai proses pemindahan air dengan menggunakan panas dan aliran udara untuk mencegah atau menghambat pertumbuhan jamur dan bakteri. Tujuan kegiatan ini adalah meningkatkan pemahaman mahasiswa tentang penerapan teknologi pengeringan, sehingga membantu mahasiswa menentukan minat studi pada awal semester 5. Sebanyak 40 mahasiswa terlibat dalam kegiatan pengabdian ini. Hasil dari kegiatan ini menunjukkan $80 \%$ mahasiswa lebih memahami aplikasi proses pengeringan secara keseluruhan, dari awal hingga akhir proses.
\end{abstract}

Kata Kunci: alat pengering tipe rak berputar, minat studi, pengeringan

\begin{abstract}
Drying is a process to remove water using heat and air flow, in order to prevent or inhibit the growth of fungi and bacteria. The purpose of this activity was to increase student's understanding of drying technology application, that would help the student to determine their study interest in early of the 5th semester. As many as 40 students were involved in this activity. The results of this activity showed approximately 80\% students have a better understanding regarding the application of the overall drying process, from the beginning to the final process.
\end{abstract}

Keywords: rotary type dryer, study interest, drying

\section{A. LATAR BELAKANG}

Pengeringan didefinisikan sebagai proses pemindahan air dengan menggunakan panas dan aliran udara untuk mencegah atau menghambat pertumbuhan jamur dan bakteri sehingga tidak dapat berkembang lagi atau berkembang namun lambat (Hall, 1980). Dasar proses pengeringan adalah terjadinya penguapan air bahan ke udara karena perbedaan kandungan uap air antara udara dengan bahan yang dikeringkan. Agar suatu bahan dapat kering, maka udara harus memiliki kandungan uap air atau kelembaban nisbi yang lebih rendah dari bahan yang akan dikeringkan. Selama proses pengeringan terjadi dua proses yaitu proses pindah panas dan pindah massa air yang terjadi secara simultan. Panas dibutuhkan untuk menguapkan air bahan yang akan dikeringkan. Penguapan terjadi karena suhu bahan lebih rendah dari pada suhu udara.

Metode pengeringan adalah cara yang digunakan untuk melakukan proses pengeringan. Metode pengeringan secara umum terdiri dari dua yaitu 
pengeringan secara manual dan pengeringan secara mekanis. Pengeringan secara manual bisa disebut dengan pengeringan alami (natural drying) dan pengeringan secara mekanis disebut dengan pengeringan buatan (artificial drying)

Pada pengeringan alami (natural drying) panas pengeringan dipengaruhi dari udara sekitar atau matahari. Pengeringan alami ini bisa dilakukan dengan cara penjemuran. Pengeringan alami ini mempunyai beberapa kelemahan antara lain tergantung pada cuaca, sukar dikontrol, memerlukan tempat penjemuran yang luas, mudah terkontaminasi dan memerlukan waktu yang lama (Widodo dan Hendriadi, 2004). Pengeringan mekanis (pengeringan buatan) dilakukan dengan menggunakan panas tambahan. Keuntungannya antara lain yaitu tidak tergantung cuaca, kapasitas pengeringan dapat dipilih sesuai dengan yang diperlukan, tidak memerlukan tempat yang luas dan kondisi pengeringan dapat dikontrol (Widodo dan Hendriadi, 2004).

Pada kegiatan pengabdian ini akan diperkenalkan salah satu jenis alat pengering tipe rotary. Alat pengering ini memanfaatkan energi panas yang berasal dari energi surya dan energi biomassa. Kelebihan alat ini adalah adanya sistem rotary atau perputaran pada rak sehingga hasil pengeringan akan lebih merata.

\section{B. METODE PELAKSANAAN}

Kegiatan ini dilaksanakan pada bulan Juni 2019 bertempat di Fakultas Teknologi Pangan dan Agroindustri Universitas Mataram. Peserta yang dilibatkan dalam kegiatan ini berjumlah 40 mahasiswa. Metode pelaksanaan dilakukan dengan sosialisasi, diskusi interaktif antara dosen dan mahasiswa, serta praktek langsung di lapangan. Materi yang diberikan secara umum meliputi teknologi pengeringan bahan pangan khususnya teknologi pengeringan menggunakan pengering tipe rotary dryer. Materi disampaikan dalam tiga sesi oleh tiga pemateri yang berbeda. Pada akhir tiap sesi dilakukan evaluasi. Evalusi kegiatan dilakukan dengan memberikan pertanyaan tipe terbuka kepada mahasiswa. Hal ini bertujuan untuk menilai pemahaman mahasiswa terhadap materi yang diberikan. Tanggapan dan penguasaan materi diukur dengan memantau pertanyaan yang disampaikan peserta kepada penyaji materi; keaktifan peserta saat melakukan praktek dan kehadiran peserta. Selain itu, indikator baiknya pemahaman mahasiswa dapat dilihat dari kemampuan mahasiswa dalam mengulang kembali materi yang disampaikan oleh pemateri (dosen).

\section{HASIL DAN PEMBAHASAN}

Kegiatan pengabdian ini dikhususkan untuk mahasiswa Teknik Pertanian semester 4 Fakultas Teknologi Pangan dan Agroindustri Universitas Mataram. Pada semester 4, mahasiswa memerlukan banyak bekal ilmu pengetahuan, baik secara teori maupun praktek yang tidak 
dapat disampaikan hanya melalui kuliah tatap muka 2 SKS (setara 100 menit) dan praktikum 1 SKS (setara 50 menit). Bekal ilmu inilah yang nantinya menjadi dasar pemilihan minat studi untuk mahasiswa semester 5 .

Masalah yang dihadapi oleh mahasiswa saat ini adalah kurangnya pemahaman yang mereka dapatkan selama kuliah tatap muka dan tugas. Kuliah tatap muka dan tugas cenderung bersifat teoritis yang pada akhirnya mahasiswa sulit untuk menerapkan pada kondisi di lapangan jika mereka sudah lulus.

Dari pemaparan masalah tersebut maka tim pengabdian mengadakan kegiatan pengabdian yang berjudul "Introduksi Alat Pengering Tipe Rotary Sebagai Upaya Mempercepat Proses Pengeringan Hasil Petanian" dengan tujuan (1) sebagai persiapan mahasiswa untuk menentukan minat studi pada semester 5, dan (2) memberikan pemahaman dengan penerapan teknologi pengeringan secara langsung kepada mahasiswa

Pada pelaksanaan kegiatan, materi disampaikan oleh anggota tim pengabdian secara bergantian. Pertama-tama disampaikan secara detail mengenai pengeringan, dimulai dari definisi, tujuan dan proses selama pengeringan berlangsung. Teknologi pengeringan hasil pertanian saat ini menjadi penting untuk dilakukan karena hasil pertanian memiliki ratarata kadar air di atas $80 \%$, artinya produk hasil pertanian segar akan rentan terhadap kerusakan jika disimpan terlalu lama. Masalah yang muncul terutama adalah terjadinya pembusukan (Winarno et al.,1980). Jika semakin banyak produk yang busuk atau rusak, maka hal ini akan berimbas kepada keuntungan dari petani yang semakin kecil. Hal inilah yang memicu adanya teknologi pengeringan. Tujuan dari pengeringan ini adalah untuk untuk pengawetan. Selain itu, tujuan dari pengeringan juga untuk meningkatkan daya tahan, mengurangi biaya pengemasan, mengurangi bobot pengangkutan, memperbaiki cita rasa bahan, dan mempertahankan kandungan nutrisi bahan (Achanta dan Okos, 2000).

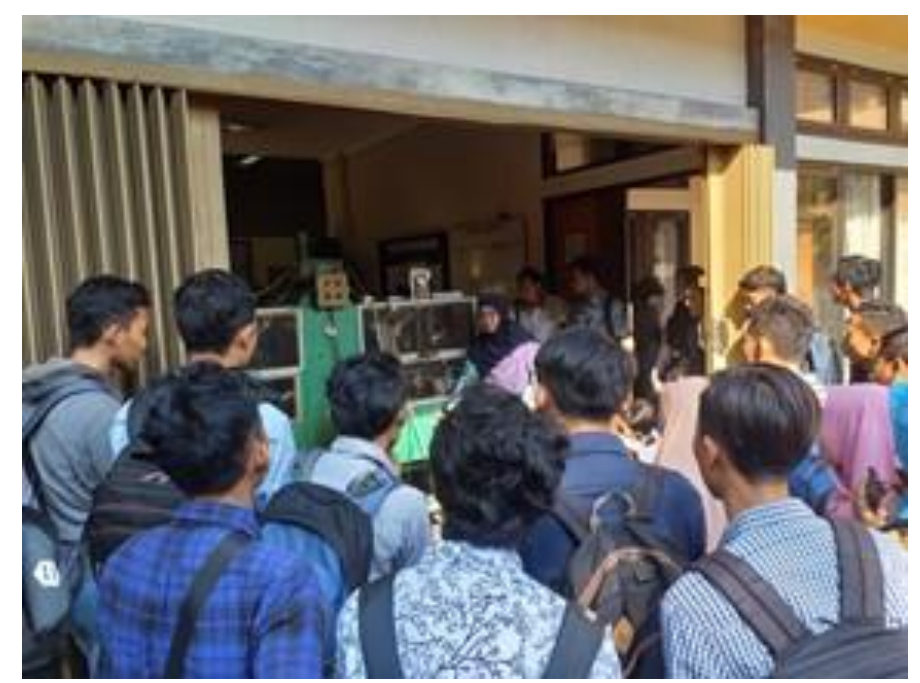

Gambar 1. Penyampaian Materi Konsep Pengeringan 
Proses pengeringan pada prinsipnya menyangkut proses pindah panas dan pindah massa yang terjadi secara bersamaan (simultan). Pertama panas harus ditransfer dari medium pemanas ke bahan. Selanjutnya setelah terjadi penguapan air, uap air yang terbentuk harus dipindahkan melalui struktur bahan ke medium sekitarnya. Proses ini akan menyangkut aliran fluida dimana cairan harus ditransfer melalui struktur bahan selama proses pengeringan berlangsung. Jadi, panas harus disediakan untuk menguapkan air dan air harus mendifusi melalui berbagai macam tahanan agar dapat lepas dari bahan dan berbentuk uap air yang bebas. Lama proses pengeringan tergantung pada bahan yang dikeringkan dan cara pemanasan yang digunakan (Rahmawan, 2001).

Faktor-faktor yang mempengaruhi pengeringan ada dua golongan yaitu faktor yang berhubungan dengan udara pengering dan faktor yang berhubungan dengan sifat bahan yang dikeringkan. Faktor-faktor yang termasuk golongan pertama adalah suhu, kecepatan volumetric, aliran udara pengering dan kelembaban udara. Faktor-faktor yang termasuk golongan kedua adalah ukuran bahan, kadar air awal dan tekanan parsial di dalam bahan (Taufiq, 2004)

Setelah mahasiswa memahami konsep dasar pengeringan, tim menyampaikan materi selanjutnya mengenai jenis alat pengering yang paling sering digunakan. Jenis alat pengering pertama adalah (1) Fluidized bed dryer. Proses pengeringan yang terjadi pada alat ini adalah dengan memanfaatkan aliran udara panas dengan kecepatan tertentu yang dilewatkan menembus hamparan bahan sehingga hamparan bahan tersebut memiliki sifat seperti fluida (Kunii dan Levenspiel, 1977). Metode pengeringan fluidisasi digunakan untuk mempercepat proses pengeringan dan mempertahankan mutu bahan kering. Alat pengering kedua adalah (2) Tray Type Dryer, yaitu alat pengering yang mempunyai bentuk persegi dan di dalamnya berisi rak yang digunakan sebagai tempat bahan yang akan dikeringkan. Rak ini ada yang dapat dikeluarkan dan ada yang tidak dapat dikeluarkan. Bahan diletakkan di atas rak (tray) yang terbuat dari logam yang berlubang. Kegunaan lubang-lubang tersebut adalah untuk mengalirkan udara panas. Alat pengering terakhir adalah (3) Rotary Type Dryer, yaitu alat pengering yang mirip dengan alat pengering tipe rak, namun rak yang digunakan bersifat dinamis, dapat berputar ke arah vertikal. Adapun pada kegiatan pengabdian ini, tim memperkenalkan alat pengering tipe rak berputar. 


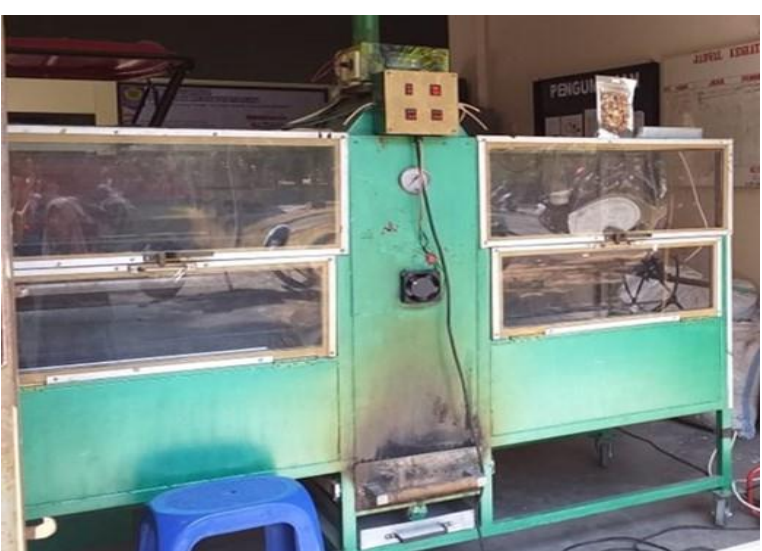

a

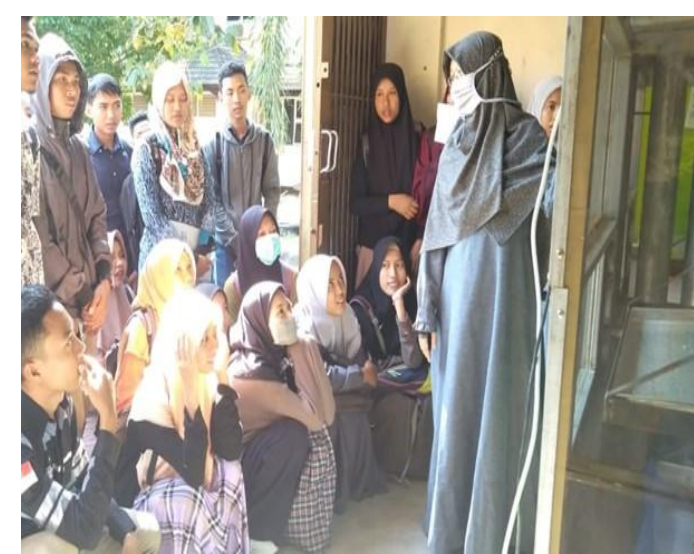

b

Gambar 2. (a) Alat Pengering Tipe Rak Berputar (b) Penyampaian Materi Bagian Alat Pengering

Alat yang didesain oleh tim pengabdian ini terdiri dari dua bagian ruang pengering, yaitu sebelah kanan dan kiri yang berdinding transparan agar energi surya dapat masuk ke dalam ruang pengering sebagai sumber pemanas. Di dalam ruang pengering terdapat empat buah rak persegi panjang yang dapat berputar dengan bantuan motor. Pada bagian tengah alat pengering terdapat alat penukar panas atau heat exchanger yang berfungsi untuk memindahkan energi kalor dari tungku biomassa ke ruang pengering. Pada bagian bawah terdapat tungku biomassa yang berfungsi sebagai sumber pemanas tambahan ketika sumber pemanas dari matahari kurang optimal. Pada bagian atas terdapat cerobong keluarnya asap dan pada dinding ruang pengering terdapat blower yang berfungsi untuk menarik energi panas dari heat exchanger masuk ke dalam ruang pengering serta membuang uap air dari bahan ke lingkungan.

Materi terakhir yang disampaikan oleh tim adalah mengenai mekanisme sistem kontrol dalam alat pengering. Sistem kontrol dalam alat pengering berfungsi sebagai alat untuk memantau (monitoring) dan mengendalikan (controlling) agar suhu dalam ruang pengering tetap stabil. Sistem kontrol ini dibangun dengan menggunakan perangkat mikorokontroler Arduino uno yang dilengkapi dengan LCD untuk menampilkan pembacaan suhu, relay untuk mengendalikan blower agar suhu tetap stabil, dan sensor DS18B20 yang berfungsi membaca suhu dalam ruang pengering. Sistem kontrol ini bekerja secara real time dan datanya tercatat secara otomatis dalam microSD yang diatur melalui RTC.

Setelah semua materi disampaikan, dilanjutkan dengan kegiatan pengoperasian alat pengering. Alat ini dapat dioperasikan dengan mudah karena sudah terdapat modul saklar yang terdiri dari satu buah saklar untuk mengatur sistem kelistrikan alat pengering dan tiga buah saklar untuk mengatur kelistrikan blower. 


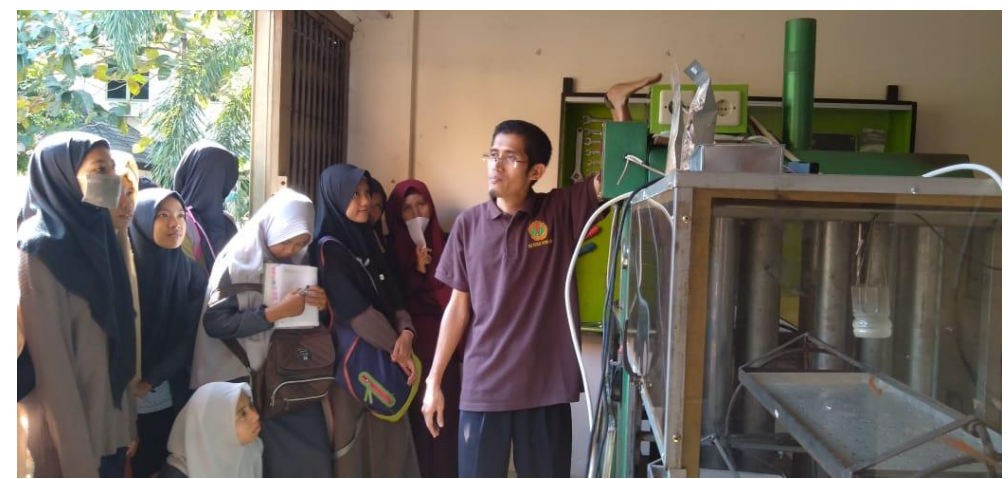

(a)

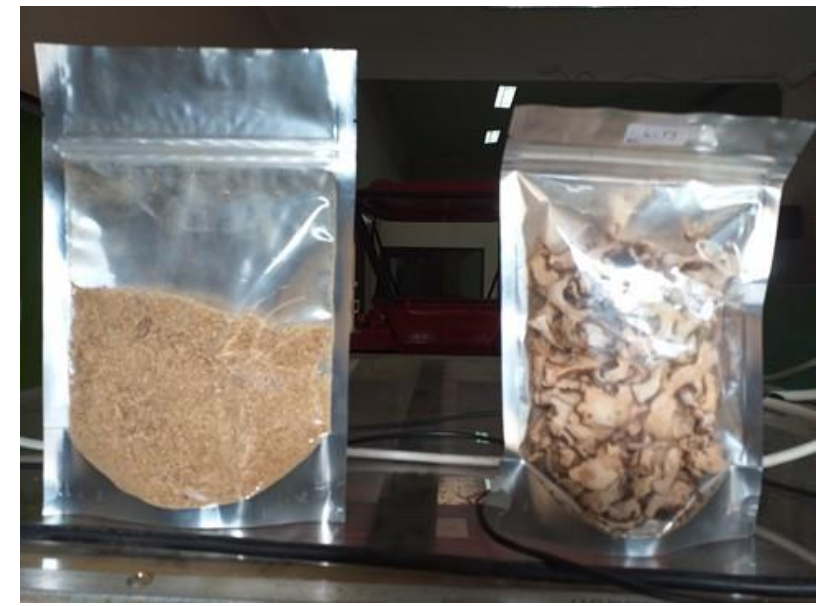

(b)

Gambar 3. (a) Penjelasan Mekanisme Sistem Kontrol (b) Produk Hasil Pengeringan

Pada akhir kegiatan, mahasiwa diperlihatkan produk dari proses pengeringan menggunakan alat pengering tipe rak berputar yang diperkenalkan oleh tim. Contoh produk yang dikeringkan adalah potongan lengkuas dengan tebal $3 \mathrm{~mm}$. Kadar air awal dari produk ini berkisar $80 \%$ dan mampu dikeringkan sampai 10\% dalam waktu 23 jam.

\section{SIMPULAN DAN SARAN}

Kegiatan pengabdian mengenai introduksi alat pengering tipe rak berputar berjalan dengan lancar. Kurang lebih 80\% mahasiswa lebih memahami materi mengenai aplikasi proses pengeringan secara keseluruhan dari awal hingga proses akhir, sehingga nantinya tidak mengalami kesulitan dalam memilih minat studi. Saran dari kegiatan ini adalah perlu membandingkan dengan jenis alat pengering yang lain sehingga diharapkan mahasiswa memahami prinsip kerja semua alat pengering beserta kelebihan dan kekurangannya.

\section{DAFTAR RUJUKAN}

[1] Achanta, S., and Okos, M.R. (2000). Quality Changes During Drying of Food Polymers. In: Mujumdar Arun S (ed). Drying Technology in Agriculture and Food Science. USA: Science Publishers, Inc., h. 133-145. 
Sukmawaty, Pengering Tipe Berputar...

[2] Hall, C.W. (1980). Drying and Storage of Agricultural. USA: Westport Connecticut The AVI Publ. Company.

[3] Kunii, D. and Levenspiel, O. (1977). Fluidization Engineering, Original Edition. New York: Robert E/ Krieger Publishing Co.

[4] Rahmawan, O. (2001). Pengeringan, Pendinginan dan Pengemasan Komoditas Pertanian. Jakarta: Depdiknas.

[5] Taufiq, M. (2004). Pengaruh Temperatur Terhadap Laju Pengeringan Jagung Pada Pengeringan Konvensional dan Fluidized Bed. (Skripsi). Surakarta: Fakultas Teknik, Universitas Sebelas Maret.

[6] Widodo, P., dan A. Hendriadi. (2004). Perbandingan kinerja Mesin Pengering jagung tipe bak datar model segiempat dan silinder. Jurnal Engineering Pertanian, Badan Penelitian dan Pengembangan Pertanian, 2 (1).

[7] Winarno, F.G., S. Fardiaz, dan D. Fardiaz. (1980). Pengantar Teknologi Pangan. Jakarta: Gramedia Pustaka Utama. 